\title{
Effect of investigational kisspeptin/metastin analog, TAK-683, on luteinizing hormone secretion at different stages of the luteal phase in goats
}

\author{
Larasati Puji RAHAYU ${ }^{1,2)}$, Mohammed El BEHIRY3), Natsumi ENDO ${ }^{1,2)}$ and \\ Tomomi TANAKA ${ }^{1,2)}$ \\ 1) Laboratory of Veterinary Reproduction, Tokyo University of Agriculture and Technology, Tokyo 183-8509, Japan \\ 2) United Graduate School of Veterinary Sciences, Gifu University, Gifu 501-1193, Japan \\ ${ }^{3)}$ Visiting Research Scientist from Egypt, Tokyo University of Agriculture and Technology, Tokyo 183-8509, Japan
}

\begin{abstract}
This study aimed to examine the response of luteinizing hormone (LH) secretion and ovarian steroid profile to TAK-683, an investigational metastin/kisspeptin analog, through treatment during different stages of the luteal phase in goats. Nine cycling Shiba goats $(4.4 \pm 2.3$ years old) were assigned to early luteal phase $(E L P, n=4)$, mid-luteal phase $(M L P, n=4)$, and control $(\mathrm{n}=5)$ groups. The ELP and MLP groups were administered $50 \mu \mathrm{g}$ of TAK-683 intravenously on either day 5 or between days 7-14 after ovulation, respectively. The control group received vehicle between days 7-14 after ovulation. Blood samples were collected at 10-min (2-6 h), 2-h (6-24 h), and 24-h (24-96 h) intervals after treatment. Significant increases in plasma LH concentration were detected during the periods of 3 to $5 \mathrm{~h}$ and 2 to $5 \mathrm{~h}$ in the ELP and MLP groups, respectively. Estradiol concentrations continuously increased with the rise of basal LH secretion after TAK-683 treatment in two goats of the ELP group with a surge-like release of LH, but not in the goats without LH surge, i.e. the MLP and control group ones. Plasma progesterone concentration and the lengths of estrous cycle in all groups did not change significantly from the time before and after treatment. Present findings indicate that the responses of LH and ovarian steroids to treatment with TAK683 depend on the stage of the luteal phase of the estrous cycle. We suggest that the stimulatory effects of TAK-683 on LH secretion are reduced in the process leading to the mid-luteal phase in cycling goats.
\end{abstract}

Key words: Goats, Luteal phase, Luteinizing hormone (LH) secretion, TAK-683

(J. Reprod. Dev. 63: 221-226, 2017)

K sspeptin is mainly produced in the hypothalamus and is biologically active at various lengths of 10 to 54 amino acids. Kisspeptin-54 or kisspeptin-10, either the full length or the C-terminal amidated 10-amino-acid sequence of kisspeptin, potently stimulates luteinizing hormone (LH) secretion in both male and female mammals [1-7]. Our previous study showed that the stimulatory action of kisspeptin-10 on LH secretion is attributable to the stimulation of gonadotropin-releasing hormone $(\mathrm{GnRH})$ neurosecretion into the hypophyseal portal circulation in castrated goats [8]. Kisspeptin is also involved in the hypothalamic regulation of $\mathrm{GnRH}$ secretion by gonadal steroids. Several lines of evidence suggest that the hypothalamic kisspeptin neurons expressing receptors for androgens, estrogens, and progesterone are implicated in the negative feedback control of $\mathrm{GnRH} /$ gonadotropin secretion [1]. From the clinical point of view, the ability of kisspeptin to induce LH secretion makes it a suitable target for the pharmacological manipulation of the gonadotropic axis.

TAK-683 is an investigational kisspeptin analog, developed for

Received: December 27, 2016

Accepted: February 1, 2017

Published online in J-STAGE: March 25, 2017

(C)2017 by the Society for Reproduction and Development

Correspondence: T Tanaka (e-mail: tomomit@cc.tuat.ac.jp)

This is an open-access article distributed under the terms of the Creative Commons Attribution Non-Commercial No Derivatives (by-nc-nd) License. (CC-BY-NC-ND 4.0: https://creativecommons.org/licenses/by-nc-nd/4.0/) clinical use as a synthetic peptide consisting of nine amino acids and having similar activity to the full-length peptide [9]. Previous studies demonstrated that a bolus administration of TAK-683 was able to stimulate LH secretion in rats [10] and goats [11]. In contrast, continuous exposure to TAK-683 strongly suppressed pulsatile LH secretion in male rats [12], and castrated [11] and ovariectomized goats [13].

Recent studies indicated that the response of LH secretion to a bolus administration of kisspeptin analog depends on the ovarian status at different stages of the reproductive cycle. One of the studies reported that the increase in the absolute value of plasma LH concentration after an administration of $\mathrm{C} 6$, another investigational kisspeptin analog, is much higher in the breeding season than that in the non-breeding season, in ewes [14]. The secretory pattern of LH secretion after a single injection of TAK-683 is characterized by episodic increases with a relatively small amplitude in ovariectomized goats. On the other hand, when TAK-683 was injected in goats in the follicular phase of the estrous cycle, a surge-like release of LH followed by ovulation was induced after treatment [15]. Despite these findings, there is little information available regarding the effect of kisspeptin analogs on LH secretion during the luteal phase. Interestingly, small increases in the basal LH secretion were transiently observed for several hours after TAK-683 administration and then a surge-like release of $\mathrm{LH}$ occurred in female goats treated with progesteronereleasing controlled internal drug releasing (CIDR) devices [16]. 
As in the follicular phase, these findings indicate that TAK-683 has the potential to induce LH surge even in the endocrine milieu of the luteal phase.

Therefore, in this study, we examined the endocrinal response to a single injection of TAK-683 during the luteal phase in goats. This paper reports changes in the $\mathrm{LH}$ concentrations after an administration of TAK-683 and their association with secretion of ovarian steroids at the different stages of the luteal phase, i.e. early- and mid-luteal phases, of the estrous cycle in goats.

\section{Materials and Methods}

\section{Animals}

Nine cycling Shiba goats $(4.4 \pm 2.3$ years of age; $30.3 \pm 5.9 \mathrm{~kg}$ in body weight) maintained at the Tokyo University of Agriculture and Technology were used. Shiba goats are non-seasonal breeders under the natural daylight conditions in Japan. The goats were housed in outdoor paddocks with sheltered areas and were fed alfalfa hay cubes (660 g of dry matter/day), with clean water and mineral salt blocks available ad libitum. They were kept individually in cages temporarily when they were subjected to treatment and frequent blood sampling. All procedures were approved by the University Committee for the Use and Care of Animals, of the Tokyo University of Agriculture and Technology (Nos. 22-67).

\section{Experimental procedure}

Cycling goats were assigned to three groups: early luteal phase (ELP, $n=4)$, mid-luteal phase (MLP, $n=4)$, and control $(n=5)$ groups. Two goats (\#4 and \#24) were utilized first in the ELP group and then in the control or MLP group, respectively. One goat (\#22) was first utilized in the control group, then the ELP group, and lastly in the MLP group. The goats were kept untreated for at least one estrous cycle before they were assigned to the other groups.

After detection of ovulation by ultrasound, the ELP and MLP groups received an intravenous administration of $50 \mu \mathrm{g}$ of TAK- 683 on either day 5 after ovulation or between days 7 and 14 (mean \pm SD, $9.3 \pm$ 1.7 days) after ovulation, respectively. During the period between days 7 and 14 after ovulation, the corpus luteum was considered to have been fully developed, as described previously [17]. The dosage of TAK-683 was determined based on previous studies [15, 16], i.e. $50 \mu \mathrm{g}$ ( $35 \mathrm{nmol})$ diluted in $5 \mathrm{ml}$ of physiological saline, for injection purposes. The chemical profile of TAK-683 has been described previously [9]. Meanwhile, the control group received 5 $\mathrm{ml}$ of physiological saline between day 7 and day 14 after ovulation (mean $\pm \mathrm{SD}, 9.4 \pm 1.3$ days).

Blood samples were taken via an indwelling catheter (18-gauge, $30 \mathrm{~cm}$ in length; Argyle ${ }^{\mathrm{TM}}$ Catheter Kit, Nippon Sherwood Medical Industries, Shizuoka, Japan) inserted into the jugular vein before the experiment. Two milliliters of blood samples were collected at 10-min (2-6 h), 2-h (6-24 h), and 24-h (24-96 h) intervals for analysis of LH, progesterone, and estradiol. Samples were centrifuged at $4^{\circ} \mathrm{C} 3000 \mathrm{rpm}$; then, the separated plasma was kept at $-20^{\circ} \mathrm{C}$ until being assayed.

Transrectal ultrasounds (HS-1500V, Honda Electronics, Aichi, Japan) with a 7.5-MHz linear probe (HLS-375M, Honda Electronics) were conducted at $24-\mathrm{h}$ intervals or every other day to detect ovula- tion. Ovulation was defined as the disappearance of a large follicle, which was reconfirmed by the development of corpus luteum at the same location.

\section{Hormone assay}

Plasma LH was assayed in duplicate using radioimmunoassay, as described previously [18]. Intra- and inter-assay coefficients of variation were $7.8 \%$ and $14.3 \%$, respectively, and sensitivity was $0.14 \mathrm{ng} / \mathrm{ml}$. Plasma estradiol-17 $\beta$ concentrations were measured using a commercially available enzyme immunoassay kit (Cayman Chemical, Ann Arbor, Michigan, USA), following extraction by dichloromethane (Wako Pure Chemical Industries, Osaka, Japan). Intra-assay coefficients of variation averaged $9.2 \%$, and sensitivity was $0.48 \mathrm{pg} / \mathrm{ml}$. Plasma progesterone concentrations were measured using enzyme immunoassays [19]. The intra-assay coefficient of variation was $9.4 \%$, and sensitivity of the assay was $0.34 \mathrm{ng} / \mathrm{ml}$.

\section{Statistical analyses}

All data are represented as mean $\pm \mathrm{SD}$; the difference between groups was determined using Kruskal-Wallis followed by Dunn's test. Time-course analysis of the LH and ovarian steroid concentration changes before and after injection, were compared using analysis of variance (ANOVA), followed by Tukey's or Dunnett's test, or Kruskal-Wallis followed by Dunn's test, according to the distribution. A confidence level of $\mathrm{P}<0.05$ was considered as statistically significant. The LH surge was defined according to a previous study that determined spontaneous LH surge in cycling goats [18]; i.e., an increase in $\mathrm{LH}$ concentration over the level of $10 \mathrm{ng} / \mathrm{ml}$ in the plasma.

\section{Results}

In all the animals in the ELP and MLP groups, the LH concentration underwent a sustained increase with a small amplitude from 0 to $6 \mathrm{~h}$ after injection. In the ELP group, two patterns of LH responses were found (Fig. 1). A surge-like release of LH was detected in 2 out of the 4 goats, but not in the other two goats. The mean LH concentrations from 0 to $6 \mathrm{~h}$ after injection were $1.1 \pm 0.4,1.0 \pm 0.3$, and $0.6 \pm 0.2$ $\mathrm{ng} / \mathrm{ml}$ in the ELP, MLP, and control groups, respectively. Increase in the LH concentration with a relatively small amplitude occurred within $6 \mathrm{~h}$ after treatment, with mean peak values of $2.7 \pm 2.8$ and $1.9 \pm 0.6 \mathrm{ng} / \mathrm{ml}$ in the ELP and MLP groups, respectively. In both ELP and MLP groups, significant increases in LH concentration were detected during the periods of 3 to $5 \mathrm{~h}$ and 2 to $5 \mathrm{~h}$, respectively, compared with that at $0 \mathrm{~h}$ relative to injection (Fig. 2).

Changes in plasma estradiol and LH concentrations from -2 to $24 \mathrm{~h}$ in all the goats in the ELP and MLP groups are shown in Fig. 3 . The concentrations of estradiol in the two goats (\#3, \#4) showing the LH surge, continued to increase in parallel with the rise of basal LH concentration until $8 \mathrm{~h}$ after injection, with peak values of 18.7 and $12.5 \mathrm{pg} / \mathrm{ml}$, respectively. The continuous elevation of estradiol levels were followed by robust increases in LH levels, and reached peak values of 18.4 and $12.8 \mathrm{ng} / \mathrm{ml}$, at 12 and $14 \mathrm{~h}$ respectively (left panels, Fig. 3). Meanwhile in the other two goats of the ELP group, estradiol concentration did not increase after injection; hence, a surge-like release of LH did not occur. The continuous increase in estradiol concentration after TAK-683 injection was not observed in 

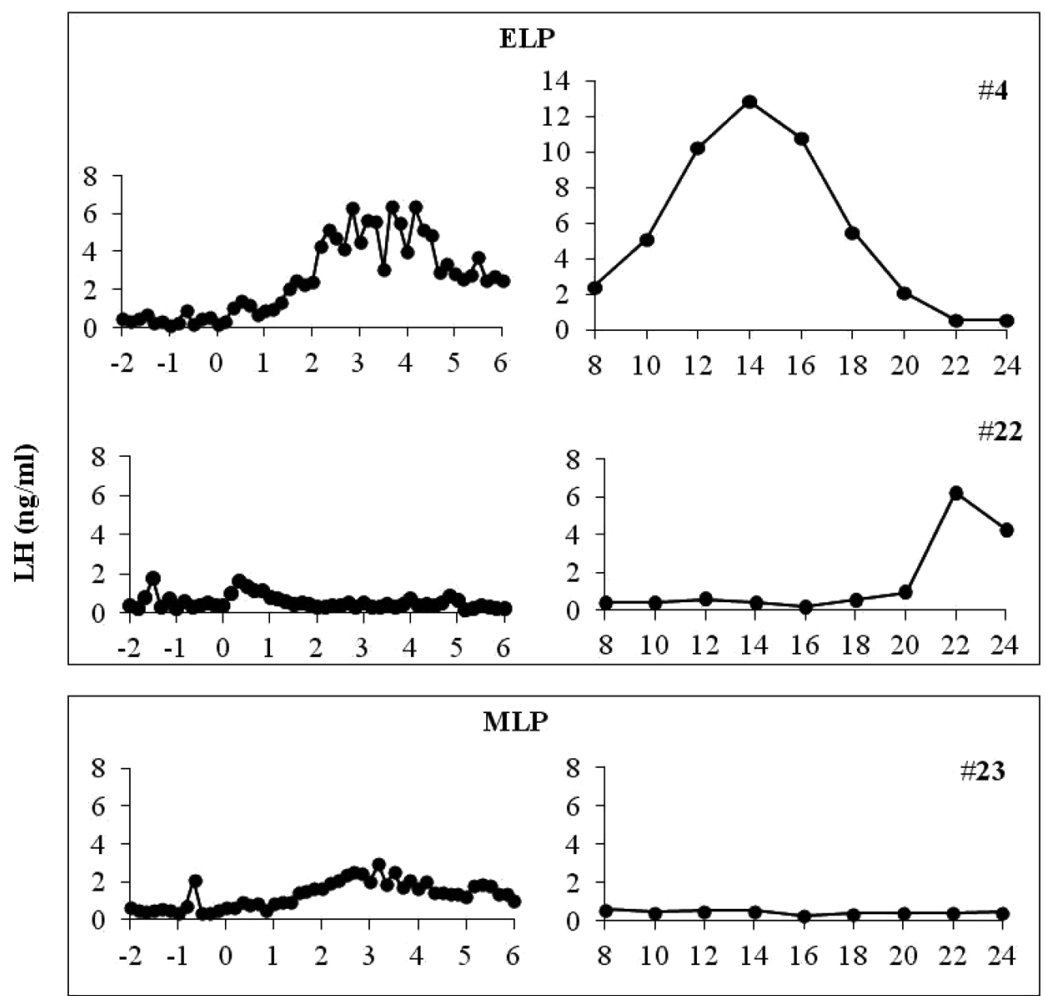

Time after injection (h)

Fig. 1. Representative profiles of LH after TAK-683 treatment in ELP (upper box) and MLP (lower box) groups. A surge-like release of LH was detected at around $14 \mathrm{~h}$ after treatment in goat \#4 from the ELP group, whereas no surge occurred in goat \#22 (ELP) and \#23 (MLP).

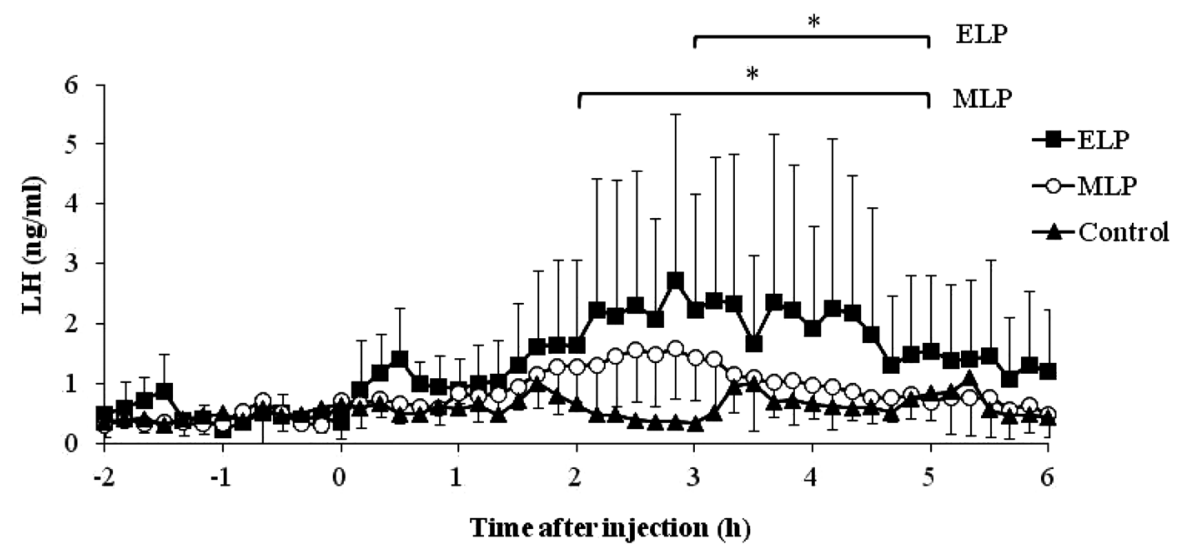

Fig. 2. Mean plasma LH concentration from -2 to $6 \mathrm{~h}$ after TAK-683 treatment in the early luteal phase (ELP) and mid-luteal phase (MLP), compared with the control group. Asterisks indicate significant differences, compared with the value at $0 \mathrm{~h}$ after treatment $(\mathrm{P}<0.05)$.

any of the goats in the MLP group (right panels, Fig. 3).

In the MLP group, the mean plasma progesterone concentration did not change significantly at $24 \mathrm{~h}$ after injection, i.e. $12.3 \pm 2.4 \mathrm{ng} /$ $\mathrm{ml}$, compared with that at $0 \mathrm{~h}$ (just before TAK-683 injection), i.e. $10.9 \pm 4.7 \mathrm{ng} / \mathrm{ml}$. Although the mean progesterone concentration of the ELP group on the day of treatment was relatively lower than that of the MLP group $(6.5 \pm 2.3 v s .10 .9 \pm 4.7 \mathrm{ng} / \mathrm{ml} ; \mathrm{P}=0.06)$, there was no significant difference between the ELP, MLP, and control $(9.5 \pm 2.3 \mathrm{ng} / \mathrm{ml})$ groups.

Ovulations were detected within 48 hours after injection in the two goats with LH surge in the ELP group, but not in the other goats. The average length of estrous cycle after treatment in the 
ELP
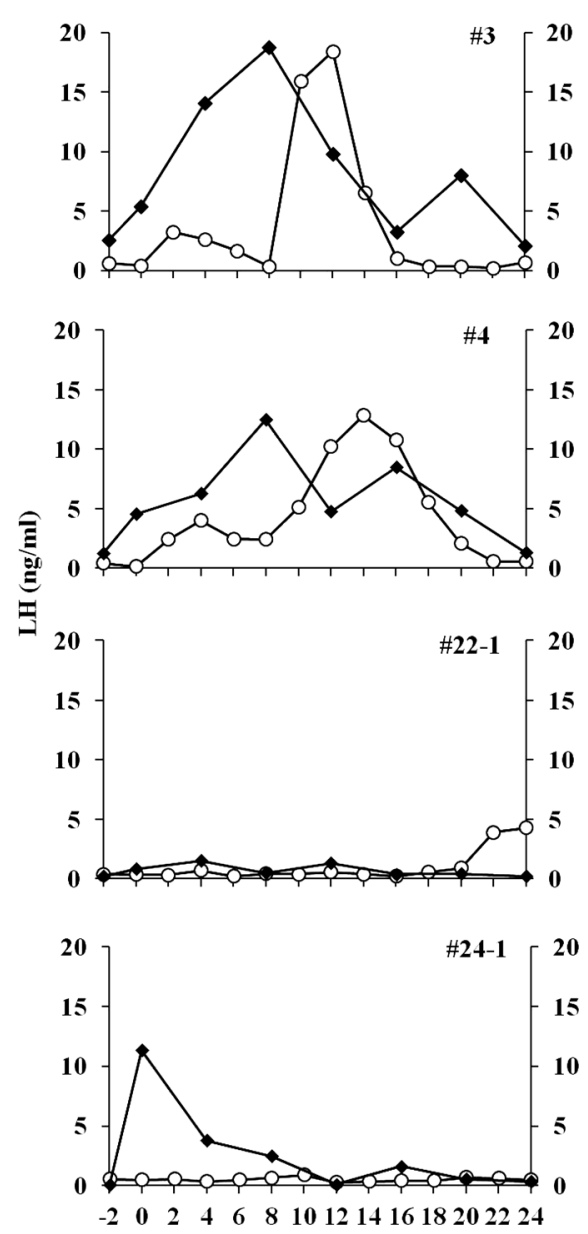

MLP
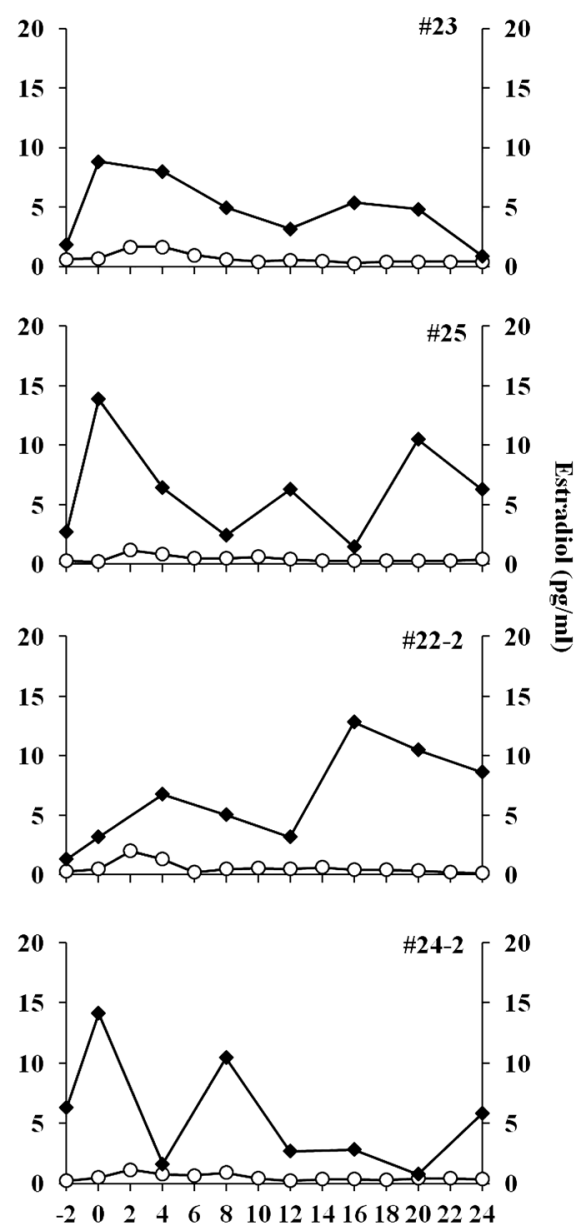

Time after injection (h)

Fig. 3. Individual profiles of plasma LH (open circle) and estradiol (closed square) in goats from the ELP (left panels) and MLP (right panels) groups. The $0 \mathrm{~h}$ indicates the time just before injection of TAK- 683 .

ELP, MLP, and control groups were $21.5 \pm 3.0,19.8 \pm 1.0$, and 18.8 \pm 1.8 days, respectively. There was no significant difference in the average length of estrous cycle among all groups.

\section{Discussion}

Contrary to our previous findings in the follicular phase [16], no LH surge was observed after a bolus administration of TAK-683 during the mid-luteal phase in goats. On the other hand, half of the four goats in the ELP group showed a response similar to that of goats treated with progesterone-releasing CIDR; LH surge occurred, with the peak time around $12 \mathrm{~h}$ after TAK-683 administration [16]. A small amplitude increase in LH secretion was observed within the initial $6 \mathrm{~h}$ after administration, in both the ELP and MLP groups. It can be summarized that the responses of surge mode secretions of LH to the treatment with TAK-683 depend on the stage of the luteal phase and that the stimulatory effects of TAK-683 on LH secretion are reduced in the process leading to the mid-luteal phase.

As described above, our previous study demonstrated that TAK-683 treatment induces a surge-like release of LH in goats treated with CIDR [16]. CIDR is well-known as a standard tool used to mimic the endocrine milieu of the luteal phase in cows [20], ewes [21], and goats [22]. A number of studies demonstrated that plasma concentrations of progesterone during the CIDR treatment were maintained at a level similar to that in the natural luteal phase in ruminant species, including goats $[23,24]$. Therefore, the different reaction of LH secretion to the TAK-683 treatment between the previous (LH surge occurred) and the present (no LH surge occurred) studies was unexpected. The profile of LH secretion after TAK-683 treatment in CIDR-treated goats was characterized by a small amplitude increase followed by a significant rise in estradiol concentration in the initial $6 \mathrm{~h}$ after treatment [16]. This is similar to the present finding in the two goats showing an LH surge. Interestingly, in these goats from the ELP group, estradiol levels continued to increase gradually until $8 \mathrm{~h}$ after injection, 
then started to decrease after the LH surge occurred. On the other hand, none of the other goats in the ELP and MLP groups showed this continuous increase in the plasma estradiol concentration after TAK-683 treatment. Increase in estradiol concentration triggers the induction of a surge release of $\mathrm{GnRH}$, which in turn induces an LH surge, as described previously $[25,26]$. Another study demonstrated that the continuous infusion of kisspeptin to anestrous ewes increased the plasma level of estradiol and then induced an LH surge [27]. Kisspeptin acts as GnRH and LH stimulators, and its mechanism is regulated by estradiol $[3,28]$. Another group of researchers revealed that kisspeptin itself plays a role as a mediator of estradiol-induced positive feedback in the hypothalamus [29]. A possible interpretation for the different response of LH secretion between our present and previous studies is that estradiol is a key mediator in the action of TAK-683 on LH secretion and the lack of continuous activation of estradiol production after TAK-683 administration resulted in the failure to induce an LH surge in the mid-luteal phase.

This hypothesis is supported by the reduction of the stimulatory response of LH in the initial $6 \mathrm{~h}$ after TAK-683 treatment in the MLP group, compared with the ELP group, particularly in the two goats showing LH surge. An administration of TAK-683 at the same dose as in the present study immediately induced a robust increase in LH secretion in the follicular phase of goats [16]. It seems that sensitivity of LH stimulation to TAK-683 decreases in the progression toward the luteal phase from the follicular phase. The previous study demonstrated that a single intravenous injection of Kisspeptin-10 $(0.77 \mathrm{nmol} / \mu \mathrm{g} / \mathrm{kg})$ during the luteal phase was able to increase plasma LH levels from below $1 \mathrm{ng} / \mathrm{ml}$ at pre-treatment to reach a peak value of $1.5 \pm 0.6 \mathrm{ng} / \mathrm{ml}$, within $30 \mathrm{~min}$ after injection in goats [30]. Meanwhile, an intravenous injection of $50 \mu \mathrm{g}$ kisspeptin during natural luteal phase in sheep caused a small increase $(<1$ $\mathrm{ng} / \mathrm{ml}$ ) of LH concentration within 120 min after injection [31]. We observed a similar LH response during the mid-luteal phase; however, a mean peak $\mathrm{LH}$ value of $1.3 \pm 0.4 \mathrm{ng} / \mathrm{ml}$ was detected within $4 \mathrm{~h}$ after injection. It is well known that an increase in LH secretion in circulation promotes estradiol production from the follicle, suggesting that the stimulatory response of LH to the current TAK-683 treatment $(50 \mu \mathrm{g} / \mathrm{head})$ in the mid-luteal phase may be insufficient to maintain the continuous stimulation of estradiol secretion, which gives rise to a lack of LH surge in the mid-luteal phase. In addition, the lack of pulsatile LH stimulation by TAK-683 in half of the goats from ELP group resulted in low estradiol production; hence, the surge-like release of LH was not induced.

The general consensus is that a high circulating-progesterone concentration inhibits LH secretion from the hypothalamus, resulting in a reduction of LH concentration in the circulation [32]. However, in our previous study, when the luteal phase milieu was successfully mimicked by CIDR insertion, the LH surges could be induced by TAK-683 treatment regardless of the presence of high levels of circulating progesterone [16]. The factor(s) attenuating the reaction of LH secretion to TAK-683 treatment in the natural luteal phase in the current study, is unknown. This weakening action may be associated with the presence of mature corpora lutea, particularly during the mid-luteal phase. A recent study demonstrated that GnRH treatment acted in a different manner toward LH secretion in cows having a corpus luteum compared with those without a corpus luteum [33].
A suppressed pattern of LH was detected in cows bearing a corpus luteum, compared to that in cows with no corpus luteum. Kojima et al. [34] proposed that the presence of a corpus luteum produces factors other than progesterone that may influence pulsatile $\mathrm{LH}$ secretion. Further studies are needed to determine the physiological factor(s) being involved in the regulation of TAK-683-induced LH secretion during the luteal phase.

In conclusion, the response of LH secretion to TAK-683 treatment in the mid-luteal phase is different from that observed in our previous study, which showed the effect of TAK-683 on LH secretion in the follicular phase or in the mimicked endocrine environment of the luteal phase produced by CIDR treatment in goats. Half of the goats given TAK-683 in the early luteal phase showed a small amplitude increase in LH secretion followed by LH surge. These findings indicate that responses of LH secretions to the treatment with TAK-683 depend on the stage of the luteal phase, and it is suggested that this effect is reduced in the progression from the follicular phase to the luteal phase in cycling goats.

\section{Acknowledgements}

We thank Dr Y Mori (the University of Tokyo) and Dr AF Parlow (the Harbor-UCLA Medical Center) for providing reagents used in the radioimmunoassay of luteinizing hormone, and $\mathrm{Dr} \mathrm{H}$ Matsui (Takeda Pharmaceutical Company) for valuable discussions.

\section{References}

1. Gottsch ML, Cunningham MJ, Smith JT, Popa SM, Acohido BV, Crowley WF, Seminara S, Clifton DK, Steiner RA. A role for kisspeptins in the regulation of gonadotropin secretion in the mouse. Endocrinology 2004; 145: 4073-4077. [Medline] [CrossRef]

2. Thompson EL, Patterson M, Murphy KG, Smith KL, Dhillo WS, Todd JF, Ghatei MA, Bloom SR. Central and peripheral administration of kisspeptin-10 stimulates the hypothalamic-pituitary-gonadal axis. J Neuroendocrinol 2004; 16: 850-858. [Medline] [CrossRef]

3. Whitlock BK, Daniel JA, Wilborn RR, Rodning SP, Maxwell HS, Steele BP, Sartin JL. Interaction of estrogen and progesterone on kisspeptin-10-stimulated luteinizing hormone and growth hormone in ovariectomized cows. Neuroendocrinology 2008; 88: 212-215. [Medline] [CrossRef]

4. Barb CR, Hausman GJ, Kraeling RR. Luteinizing hormone secretion as influenced by age and estradiol in the prepubertal gilt. Anim Reprod Sci 2010; 122: 324-327. [Medline] [CrossRef]

5. Caraty A, Smith JT, Lomet D, Ben Saïd S, Morrissey A, Cognie J, Doughton B, Baril G, Briant C, Clarke IJ. Kisspeptin synchronizes preovulatory surges in cyclical ewes and causes ovulation in seasonally acyclic ewes. Endocrinology 2007; 148: 5258-5267. [Medline] [CrossRef]

6. Messager S, Chatzidaki EE, Ma D, Hendrick AG, Zahn D, Dixon J, Thresher RR, Malinge I, Lomet D, Carlton MB, Colledge WH, Caraty A, Aparicio SA. Kisspeptin directly stimulates gonadotropin-releasing hormone release via $\mathrm{G}$ protein-coupled receptor 54. Proc Natl Acad Sci USA 2005; 102: 1761-1766. [Medline] [CrossRef]

7. Dhillo WS, Chaudhri OB, Thompson EL, Murphy KG, Patterson M, Ramachandran R, Nijher GK, Amber V, Kokkinos A, Donaldson M, Ghatei MA, Bloom SR. Kisspeptin-54 stimulates gonadotropin release most potently during the preovulatory phase of the menstrual cycle in women. J Clin Endocrinol Metab 2007; 92: 3958-3966. [Medline] [CrossRef]

8. Tanaka T, Ohkura S, Wakabayashi Y, Okamura H. Effect of peripherally administered kisspeptin-10 on GnRH neurosecretion into the hypophyseal portal circulation in ovariectomized goat does. Small Rumin Res 2012; 105: 273-276. [CrossRef]

9. Yoshida N, Nishizawa N, Matsui H, Moriya Y, Kitada C, Asami T, Matsumoto $\mathbf{H}$ Development and validation of sensitive sandwich ELISAs for two investigational nonapeptide metastin receptor agonists, TAK-448 and TAK-683. J Pharm Biomed Anal 2012; 70: 369-377. [Medline] [CrossRef] 
10. Matsui H, Takatsu Y, Kumano S, Matsumoto H, Ohtaki T. Peripheral administration of metastin induces marked gonadotropin release and ovulation in the rat. Biochem Biophys Res Commun 2004; 320: 383-388. [Medline] [CrossRef]

11. Ohkura S, Tanaka T, Kuroiwa T, Wakbayashi Y, Ohtaki T, Kusaka M, Okamura H. Effects of investigational metastin/kisspeptin analog, TAK-683, on luteinizing hormone secretion in peripheral plasma, and gonadotropin-releasing hormone secretion in the pituitary portal circulation in goats. In ENDO Annual Meeting; 2011; Boston, USA. Abstract P2-273.

12. Matsui H, Tanaka A, Yokoyama K, Takatsu Y, Ishikawa K, Asami T, Nishizawa N, Suzuki A, Kumano S, Terada M, Kusaka M, Kitada C, Ohtaki T. Chronic administration of the metastin/kisspeptin analog KISS1305 or the investigational agent TAK-448 suppresses hypothalamic pituitary gonadal function and depletes plasma testosterone in adult male rats. Endocrinology 2012; 153: 5297-5308. [Medline] [CrossRef]

13. Tanaka T, Ohkura S, Wakabayashi Y, Kuroiwa T, Nagai K, Endo N, Tanaka A, Matsui H, Kusaka M, Okamura H. Differential effects of continuous exposure to the investigational metastin/kisspeptin analog TAK-683 on pulsatile and surge mode secretion of luteinizing hormone in ovariectomized goats. J Reprod Dev 2013; 59: 563-568. [Medline] [CrossRef]

14. Decourt C, Robert V, Anger K, Galibert M, Madinier JB, Liu X, Dardente H, Lomet D, Delmas AF, Caraty A, Herbison AE, Anderson GM, Aucagne V, Beltramo M. A synthetic kisspeptin analog that triggers ovulation and advances puberty. Sci Rep 2016; 6: 26908. [Medline] [CrossRef]

15. Goto Y, Endo N, Nagai K, Ohkura S, Wakabayashi Y, Tanaka A, Matsui H, Kusaka M, Okamura H, Tanaka T. Ovarian and hormonal responses to follicular phase administration of investigational metastin/kisspeptin analog, TAK-683, in goats. Reprod Domest Anim 2014; 49: 338-342. [Medline] [CrossRef]

16. Endo N, Tamesaki C, Ohkura S, Wakabayashi Y, Matsui H, Tanaka A, Watanabe T, Okamura H, Tanaka T. Differential changes in luteinizing hormone secretion after administration of the investigational metastin/kisspeptin analog TAK-683 in goats. Anim Reprod Sci 2015; 159: 87-93. [Medline] [CrossRef]

17. Orita J, Tanaka T, Kamomae H, Kaneda Y. Ultrasonographic observation of follicular and luteal dynamics during the estrous cycle in Shiba goats. $J$ Reprod Dev 2000; 46: 31-37. [CrossRef]

18. Mori Y, Kano Y. Changes in plasma concentrations of LH, progesterone and oestradiol in relation to the occurrence of luteolysis, oestrus and time of ovulation in the Shiba goat (Capra hircus). J Reprod Fertil 1984; 72: 223-230. [Medline] [CrossRef]

19. Prakash BS, Meyer HH, Schallenberger E, van de Wiel DF. Development of a sensitive enzymeimmunoassay (EIA) for progesterone determination in unextracted bovine plasma using the second antibody technique. J Steroid Biochem 1987; 28: 623-627. [Medline] [CrossRef]

20. Macmillan KL, Taufa V, Barnes DR, Day AM. Plasma progesterone concentrations in heifers and cows treated with a new intravaginal device. Anim Reprod Sci 1991; 26: 25-40. [CrossRef]
21. Godfrey RW, Collins JR, Hensley EL, Wheaton JE. Estrus synchronization and artificial insemination of hair sheep ewes in the tropics. Theriogenology 1999; 51: 985-997. [Medline] [CrossRef]

22. Romano JE. Synchronization of estrus using CIDR, FGA or MAP intravaginal pessaries during the breeding season in Nubian goats. Small Rumin Res 2004; 55: 15-19. [CrossRef]

23. Colazo MG, Kastelic JP, Davis H, Rutledge MD, Martinez MF, Small JA, Mapletoft RJ. Effects of plasma progesterone concentrations on LH release and ovulation in beef cattle given GnRH. Domest Anim Endocrinol 2008; 34: 109-117. [Medline] [CrossRef]

24. Wheaton JE, Carlson K, Windels HF, Johnston LJ. CIDR: A new progesterone device for induction of estrus and cycle control in sheep and goats. Anim Reprod Sci 1993; 33: 127-141. [CrossRef]

25. Kesner JS, Convey EM, Anderson CR. Evidence that estradiol induces the preovulatory LH surge in cattle by increasing pituitary sensitivity to LHRH and then increasing LHRH release. Endocrinology 1981; 108: 1386-1391. [Medline] [CrossRef]

26. Legan SJ, Coon GA, Karsch FJ. Role of estrogen as initiator of daily LH surges in the ovariectomized rat. Endocrinology 1975; 96: 50-56. [Medline] [CrossRef]

27. Sébert ME, Lomet D, Saïd SB, Monget P, Briant C, Scaramuzzi RJ, Caraty A Insights into the mechanism by which kisspeptin stimulates a preovulatory LH surge and ovulation in seasonally acyclic ewes: potential role of estradiol. Domest Anim Endocrinol 2010; 38: 289-298. [Medline] [CrossRef]

28. Pielecka-Fortuna J, Chu Z, Moenter SM. Kisspeptin acts directly and indirectly to increase gonadotropin-releasing hormone neuron activity and its effects are modulated by estradiol. Endocrinology 2008; 149: 1979-1986. [Medline] [CrossRef]

29. Smith JT, Li Q, Yap KS, Shahab M, Roseweir AK, Millar RP, Clarke IJ. Kisspeptin is essential for the full preovulatory $\mathrm{LH}$ surge and stimulates $\mathrm{GnRH}$ release from the isolated ovine median eminence. Endocrinology 2011; 152: 1001-1012. [Medline] [CrossRef]

30. Hashizume T, Saito H, Sawada T, Yaegashi T, Ezzat AA, Sawai K, Yamashita T. Characteristics of stimulation of gonadotropin secretion by kisspeptin-10 in female goats Anim Reprod Sci 2010; 118: 37-41. [Medline] [CrossRef]

31. Li Q, Roa A, Clarke IJ, Smith JT. Seasonal variation in the gonadotropin-releasing hormone response to kisspeptin in sheep: possible kisspeptin regulation of the kisspeptin receptor. Neuroendocrinology 2012; 96: 212-221. [Medline] [CrossRef]

32. Niswender GD, Juengel JL, Silva PJ, Rollyson MK, McIntush EW. Mechanisms controlling the function and life span of the corpus luteum. Physiol Rev 2000; 80: 1-29. [Medline]

33. Stevenson JS, Pulley SL. Feedback effects of estradiol and progesterone on ovulation and fertility of dairy cows after gonadotropin-releasing hormone-induced release of luteinizing hormone. J Dairy Sci 2016; 99: 3003-3015. [Medline] [CrossRef]

34. Kojima N, Stumpf TT, Cupp AS, Werth LA, Roberson MS, Wolfe MW, Kittok RJ, Kinder JE. Exogenous progesterone and progestins as used in estrous synchrony regimens do not mimic the corpus luteum in regulation of luteinizing hormone and $17 \beta$-estradiol in circulation of cows. Biol Reprod 1992; 47: 1009-1017. [Medline] [CrossRef] 